\title{
Study to Assess the Effect of Breed, Season and Breed $x$ Season Interaction on Maintenance Behavior of Stud Bulls
}

\author{
Tripti Kumari*, S. Pan and R. K. Choudhary \\ ICAR-National Dairy Research Institute, Karnal - 132001, Haryana, India \\ *Corresponding author
}

\begin{abstract}
A B S T R A C T
Stud bulls play a unique role in cattle breeding due to its high genetic potential. To maintain its characteristics, better health condition is necessary which can be achieved if it exhibitsits maintenance behavior normally. Hence, aim of the present study was to assess the effect of breed, season and breed $\mathrm{x}$ season interaction on the maintenance behavior (viz., amount of feed consumed, eating, drinking, rumination, standing, sitting, lying and sleeping time) of stud bulls. Twenty bulls (five from each four different breeds i.e. Sahiwal, Gir, Jersey cross and H. F. cross) at frozen semen bull station, Haringhata, Nadia, West Bengal, India during two seasons i.e., winter and summer were selected for the experiment. The result revealed that amount of feed consumed, eating, sitting, lying and sleeping time was significantly affected by breed at 5,5,1,1 and $1 \%$ level statistically. Season was found to have significant effect on rumination and sitting time at 5 and $1 \%$ level statistically whereas there was significant effect of breed $\mathrm{x}$ season interaction on lying $(\mathrm{P}<0.01)$ and sleeping time $(\mathrm{P}<0.01)$. All the effects were found to be non significant on drinking and standing time. Hence, information based on the study might be helpful to adopt better management practices in the farm so that bulls maintain its behavioral activities normally and perform better in each season.
\end{abstract}

\section{Introduction}

Stud bull plays a unique role in cattle breeding. The knowledge of maintenance behavior can markedly improve the efficiency and profitability, quality of life of producers and their animals and integrity of the environment (Irola et al., 2013). It includes feeding, drinking, ruminating and resting behavior (Mitlohner et al., 2001).

Feeding behavior has direct effect on growth, fertility and income (Fraser and Broom 2002).
It includes eating and drinking activity (Dumont 1996). Drinking compensates loss of liquid in the bull. This compensation is important for the natural thermoregulation of animal so that they maintain their health and survive well in the given condition.

Rumination is an important natural behavior of these animals which helps them to digest feed. It provides a more sensitive and earlier indication of an animal's health and wellness. Duration of rumination is primarily 
determined by the composition and quality of feed (Lindstrom et al., 2001). Rest reflects the comfort of the animal. It comprises various postures like sitting, standing, lying and sleeping in a normal manner (Mounaix et al., 2013). All the components of maintenance behaviorvaries according to health, age, weight, breed, species of the animal and season (consisting of various environmental factors).

The aim of the experiment was to test the hypotheses that the certain aspects of maintenance behavior of stud bulls are influenced by breed, season and interaction between breed $\mathrm{x}$ season.

\section{Materials and Methods}

The study was conducted atFrozen Semen Bull Station, Haringhata Farm under Paschim Banga Go Sampad Bikash Sangsthan, ARD Department, Government of West Bengal on twenty stud bulls (Five bulls of each four genetic groups viz., Sahiwal, Gir, Jersey cross and H.F. cross) in two seasons, viz., winter and summer. All the animals were maintained as per routine management practices of farm under uniform environment and identical condition. Offered and refusals of feed have been weighed for evaluating feed consumed by the bull per day. Hourly scan sampling method (Mialon et al., 2008) has been used for assessing other maintenance activities. Observation was recorded for two hours each at morning (9.00 to 11.00 A.M) and at afternoon (2.30 to 4.30 A.M) starting from thirty minutes prior to offering of feed and continues for one and half an hour after offering feed. Every two bulls were observed for two minutes and incidence of particular behavior(s) was noted on tabulation sheet suitably developed for the purpose. The bull(s) was again observed after 10 minutes after completing observation on other bulls in circular manner. With the help of these observations total feeding time, total drinking time, total ruminating time and total resting time in 2 hours were calculated. Accordingly, total time of observation per bull was $48 \mathrm{~min}$ per day. The data were analyzed using mixed model least squares analysis for fitting constants (Harvey 1990).

\section{Results and Discussion}

Means ( \pm S.E.) for different components of maintenance behavior have been presented in Table 1.

\section{Feed consumption}

Only the effect of breed on daily feed consumption was found to be significant $(\mathrm{P}<$ 0.05). Effect of season and breed $\mathrm{x}$ season interaction was found to be non-significant. The differences between Gir and Sahiwal, H.F. cross and Gir were significant $(\mathrm{P}<0.05)$ (Table 1). Rest of the differences were nonsignificant statistically. Out of the total feed offered Sahiwal, Gir, Jersey cross and H.F cross bulls consumed about 95, 93.4, 94.6 and $94.4 \%$ of total feed (Fig. 1). Similar finding was observed by Baumant et al., (2006). But Rastani et al., (2001) and Thomson et al., (2001) have reported lower values than the present findings, which was 3.34 and 2.8 $\mathrm{kg} / 100 \mathrm{~kg}$ live wt. in Jersey cows whereas, 3.59 and $3.03 \mathrm{~kg} / 100 \mathrm{~kg}$ live wt. in Holstein Friesian cows respectively. The significant variation found might be due to the genetic differences of the animal and their variation in adaptability to local situation.

\section{Eating time}

Effect of breed on eating time was significant statistically $(\mathrm{P}<0.01)$. Rest of the effects were non-significant. Breeds influenced the time spent in eating by the stud bulls in the order i.e., Sahiwal > Jersey cross > Gir > H.F. cross. The differences in duration of eating 
time between Sahiwal and Gir, and Jersey cross and H.F cross were found to be significant statistically (Table 1). During 48 min. of observation the total time spent eating varied from 41.39 to $43.33 \%$ (Fig. 2). Lower values than those of the presented findings have been reported by Singh et al., (1985) in cattle. This variation might be due to the genetic differences of the animal, weather and management practices.

\section{Drinking time}

All the effects (i.e., breed, season and their interaction) were found to be nonsignificantstatistically. Present findings have been supported by (Baumont et al., 2006). But they are in contradiction with the findings of Fraser and Broom (2002) who reported significant variation in drinking time between breeds and seasons.

\section{Rumination time}

Effects of season on rumination time were significant at 5\% level statistically. Present findings showed that rumination was more in summer in comparison to that during winter season. The reference is limited in the literature on the time spent ruminating by stud bulls.Similar finding was reported by Schake and Riggs (1969) in Sahiwal cattle.

But deviation from the present observation was found by Singh et al., (1985) in lactating dairy cows and buffalo. Seasonal variation in present study might be due to variation in quality of roughage offered to the bulls in different seasons and direct effect of environmental temperature on rumen physiology.

\section{Resting time}

Resting time has been classified to following four sub components.

\section{Sitting time}

Time spent in sitting posture and not performing any activity is taken as sitting time. Effects of breed and season were found significant statistically $(\mathrm{P}<0.01)$ on the parameter. The differences between Sahiwal and H.F. cross, Jersey cross and Sahiwal were significant (Table 1). Yadav and Gupta (1985) reported higher values than that of the present result whereas lower values were obtained by Thind and Gill (1986) in buffaloes. This variation might be due to the genetic differences of the animals. Bulls showed more sitting activity in summer season than that during winter season. During $48 \mathrm{~min}$. of observation the total time spent sitting varied from $7.97 \%$ to $11.54 \%$ (Fig. 2). Higher value (19.72 min out of $48 \mathrm{~min}$.) was reported by Raut (1999) in Black pied cows during summer season. Significant variation found might be due to the variation in adaptability of the breed(s) to local weather.

\section{Standing time}

This includes time spent in idle standing posture without any activity. All the effects ( i.e., breed, season and their interaction) were found to be non-significant. Contrarily Gonyou and Stricklin (1984) found that seasonal changes had significant effect on standing time.

\section{Lying time}

This refers to time spent in lying posture in idle condition. Effects of breed and breed $\mathrm{x}$ season interaction on this component of maintenance behavior were significant statistically $(\mathrm{P}<0.01)$. Differences in lying time between Gir and Sahiwal, H.F. cross and Gir, Jersey cross and Gir were found to be significant statistically (Table 1). During 48 min. of observation the total time spent lying varied from $2.63 \%$ to $4.17 \%$ (Fig.2). 
Table.1 Different components of maintenance behavior of bulls during $48 \mathrm{~min}$. per animal of scan sampling observation (Mean \pm S.E)

\begin{tabular}{|c|c|c|c|c|c|c|c|c|c|}
\hline \multirow[b]{2}{*}{ Breeds } & \multirow[b]{2}{*}{ Season } & \multirow[b]{2}{*}{$\begin{array}{c}\text { Feed } \\
\text { consumed/bu } \\
\text { ll/day } \\
\text { (kg/100kg } \\
\text { body wt.) }\end{array}$} & \multirow[b]{2}{*}{$\begin{array}{l}\text { Eating } \\
\text { time } \\
\text { (min.) }\end{array}$} & \multirow[b]{2}{*}{$\begin{array}{c}\text { Drinking } \\
\text { time (min.) }\end{array}$} & \multirow[b]{2}{*}{$\begin{array}{l}\text { Ruminat-- } \\
\text { ion time } \\
\text { (min.) }\end{array}$} & \multicolumn{4}{|c|}{ Resting Time } \\
\hline & & & & & & $\begin{array}{l}\text { Sitting } \\
\text { time } \\
\text { (min.) }\end{array}$ & $\begin{array}{c}\text { Standing } \\
\text { time } \\
(\text { min. })\end{array}$ & $\begin{array}{l}\text { Lying } \\
\text { time } \\
\text { (min.) }\end{array}$ & $\begin{array}{l}\text { Sleeping } \\
\text { time } \\
\text { (min.) }\end{array}$ \\
\hline \multirow[t]{3}{*}{ Sahiwal } & Winter & $\begin{array}{c}4.78 \pm \\
0.02\end{array}$ & $\begin{array}{c}21.48 \pm \\
0.32\end{array}$ & $\begin{array}{c}1.68 \pm \\
0.14\end{array}$ & $\begin{array}{c}5.24 \pm \\
0.29\end{array}$ & $\begin{array}{c}3.40 \pm \\
0.37\end{array}$ & $\begin{array}{c}12.72 \pm \\
0.76\end{array}$ & $\begin{array}{l}1.48 \pm \\
0.20^{\mathrm{a}}\end{array}$ & $\begin{array}{c}2.00 \pm \\
0.01\end{array}$ \\
\hline & Summer & $\begin{array}{c}4.71 \pm \\
0.02\end{array}$ & $\begin{array}{c}20.12 \pm \\
0.35\end{array}$ & $\begin{array}{c}1.24 \pm \\
0.14\end{array}$ & $\begin{array}{c}5.76 \pm \\
0.27\end{array}$ & $\begin{array}{c}4.26 \pm \\
0.33\end{array}$ & $\begin{array}{c}12.40 \pm \\
0.44\end{array}$ & $\begin{array}{l}2.52 \pm \\
0.22^{b}\end{array}$ & $\begin{array}{c}1.70 \pm \\
0.03\end{array}$ \\
\hline & Overall & $\begin{array}{l}4.75 \pm \\
0.01^{\text {acd }}\end{array}$ & $\begin{array}{c}20.80 \pm \\
0.31^{\mathrm{ACD}}\end{array}$ & $\begin{array}{c}1.46 \pm \\
0.11\end{array}$ & $\begin{array}{c}5.50 \pm \\
0.26\end{array}$ & $\begin{array}{c}3.83 \pm \\
0.23^{\mathrm{ABD}}\end{array}$ & $\begin{array}{c}12.56 \pm \\
0.53\end{array}$ & $\begin{array}{c}2.00 \pm \\
0.10^{\mathrm{ACD}}\end{array}$ & $\begin{array}{c}1.85 \pm \\
0.02^{\text {acd }}\end{array}$ \\
\hline \multirow{3}{*}{ Gir } & Winter & $\begin{array}{c}4.69 \pm \\
0.02\end{array}$ & $\begin{array}{c}20.88 \pm \\
0.35\end{array}$ & $\begin{array}{c}1.64 \pm \\
0.16\end{array}$ & $\begin{array}{c}5.16 \pm \\
0.23\end{array}$ & $\begin{array}{c}4.52 \pm \\
0.31\end{array}$ & $\begin{array}{c}13.00 \pm \\
0.56\end{array}$ & $\begin{array}{c}1.68 \pm \\
0.12\end{array}$ & $\begin{array}{c}1.12 \pm \\
0.01\end{array}$ \\
\hline & Summer & $\begin{array}{c}4.65 \pm \\
0.01\end{array}$ & $\begin{array}{c}18.92 \pm \\
0.34\end{array}$ & $\begin{array}{c}1.16 \pm \\
0.14\end{array}$ & $\begin{array}{c}7.60 \pm \\
0.29\end{array}$ & $\begin{array}{c}5.76 \pm \\
0.34\end{array}$ & $\begin{array}{c}12.08 \pm \\
0.45\end{array}$ & $\begin{array}{c}1.48 \pm \\
0.20\end{array}$ & $\begin{array}{c}1.00 \pm \\
0.03\end{array}$ \\
\hline & Overall & $\begin{array}{c}4.67 \pm \\
0.01^{\text {beg }}\end{array}$ & $\begin{array}{l}19.90 \pm \\
0.32^{\text {BEF }}\end{array}$ & $\begin{array}{c}1.40 \pm \\
0.12\end{array}$ & $\begin{array}{c}6.38 \pm \\
0.24\end{array}$ & $\begin{array}{c}5.14 \pm \\
0.24^{\mathrm{AFG}}\end{array}$ & $\begin{array}{c}12.54 \pm \\
0.37\end{array}$ & $\begin{array}{c}1.58 \pm \\
0.12^{\text {BEG }}\end{array}$ & $\begin{array}{l}1.06 \pm \\
0.01^{\text {cef }}\end{array}$ \\
\hline \multirow{3}{*}{$\begin{array}{c}\text { Jersey } \\
\text { cross }\end{array}$} & Winter & $\begin{array}{c}4.71 \pm \\
0.04\end{array}$ & $\begin{array}{c}19.92 \pm \\
0.30\end{array}$ & $\begin{array}{c}1.72 \pm \\
0.14\end{array}$ & $\begin{array}{c}4.52 \pm \\
0.23\end{array}$ & $\begin{array}{c}4.68 \pm \\
0.34\end{array}$ & $\begin{array}{c}12.80 \pm \\
0.59\end{array}$ & $\begin{array}{c}1.60 \pm \\
0.24\end{array}$ & $\begin{array}{l}2.76 \pm \\
0.01^{\mathrm{a}}\end{array}$ \\
\hline & Summer & $\begin{array}{c}4.74 \pm \\
0.03\end{array}$ & $\begin{array}{c}20.12 \pm \\
0.40\end{array}$ & $\begin{array}{c}1.16 \pm \\
0.16\end{array}$ & $\begin{array}{c}5.48 \pm \\
0.28\end{array}$ & $\begin{array}{c}6.40 \pm \\
0.41\end{array}$ & $\begin{array}{c}11.24 \pm \\
0.45\end{array}$ & $\begin{array}{c}1.36 \pm \\
0.11\end{array}$ & $\begin{array}{l}2.24 \pm \\
0.01^{b}\end{array}$ \\
\hline & Overall & $\begin{array}{l}4.73 \pm \\
0.03^{\text {cei }}\end{array}$ & $\begin{array}{c}20.02 \pm \\
0.30^{\text {CEG }}\end{array}$ & $\begin{array}{c}1.44 \pm \\
0.12\end{array}$ & $\begin{array}{c}5.00 \pm \\
0.24\end{array}$ & $\begin{array}{c}5.54 \pm \\
0.27^{\text {CFH }}\end{array}$ & $\begin{array}{c}12.02 \pm \\
0.39\end{array}$ & $\begin{array}{c}1.48 \pm \\
0.14^{\text {CFI }}\end{array}$ & $\begin{array}{c}2.50 \pm \\
0.01^{\text {beg }}\end{array}$ \\
\hline \multirow{3}{*}{$\begin{array}{l}\text { H.F. } \\
\text { cross }\end{array}$} & Winter & $\begin{array}{c}4.73 \pm \\
0.04\end{array}$ & $\begin{array}{c}20.34 \pm \\
0.36\end{array}$ & $\begin{array}{c}1.32 \pm \\
0.12\end{array}$ & $\begin{array}{c}5.48 \pm \\
0.28\end{array}$ & $\begin{array}{c}4.36 \pm \\
0.50\end{array}$ & $\begin{array}{c}13.34 \pm \\
0.67\end{array}$ & $\begin{array}{l}1.46 \pm \\
0.05^{c}\end{array}$ & $\begin{array}{c}1.70 \pm \\
0.01\end{array}$ \\
\hline & Summer & $\begin{array}{c}4.72 \pm \\
0.02\end{array}$ & $\begin{array}{c}19.41 \pm \\
0.39\end{array}$ & $\begin{array}{c}1.06 \pm \\
0.13\end{array}$ & $\begin{array}{c}5.94 \pm \\
0.25\end{array}$ & $\begin{array}{c}5.56 \pm \\
0.39\end{array}$ & $\begin{array}{c}13.24 \pm \\
0.62\end{array}$ & $\begin{array}{l}1.05 \pm \\
0.08^{d}\end{array}$ & $\begin{array}{c}1.74 \pm \\
0.04\end{array}$ \\
\hline & Overall & $\begin{array}{l}4.72 \pm \\
0.03^{\text {dhi }}\end{array}$ & $\begin{array}{c}19.87 \pm \\
0.37^{\text {DFH }}\end{array}$ & $\begin{array}{c}1.19 \pm \\
0.11\end{array}$ & $\begin{array}{c}5.71 \pm \\
0.24\end{array}$ & $\begin{array}{c}4.96 \pm \\
0.32^{\mathbf{E G H}}\end{array}$ & $\begin{array}{c}13.29 \pm \\
0.46\end{array}$ & $\begin{array}{c}1.26 \pm \\
0.05^{\mathrm{DHI}}\end{array}$ & $\begin{array}{c}1.72 \pm \\
0.01^{\text {deg }}\end{array}$ \\
\hline
\end{tabular}

Mean having different superscripts within the same column in small and capital letters differ significantly $(\mathrm{P}<0.05$ and $\mathrm{P}<0.01$ respectively)

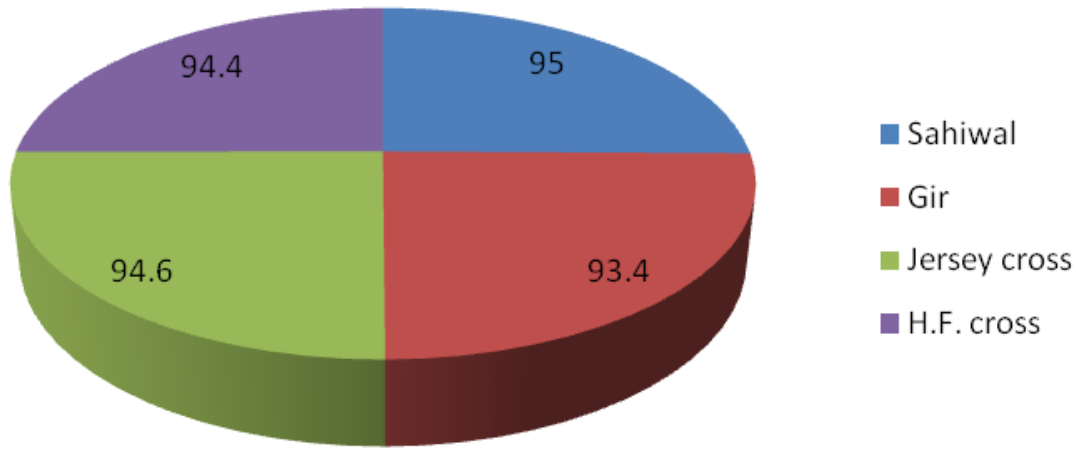

Fig.1 Feed consumed by different breeds of stud bulls 


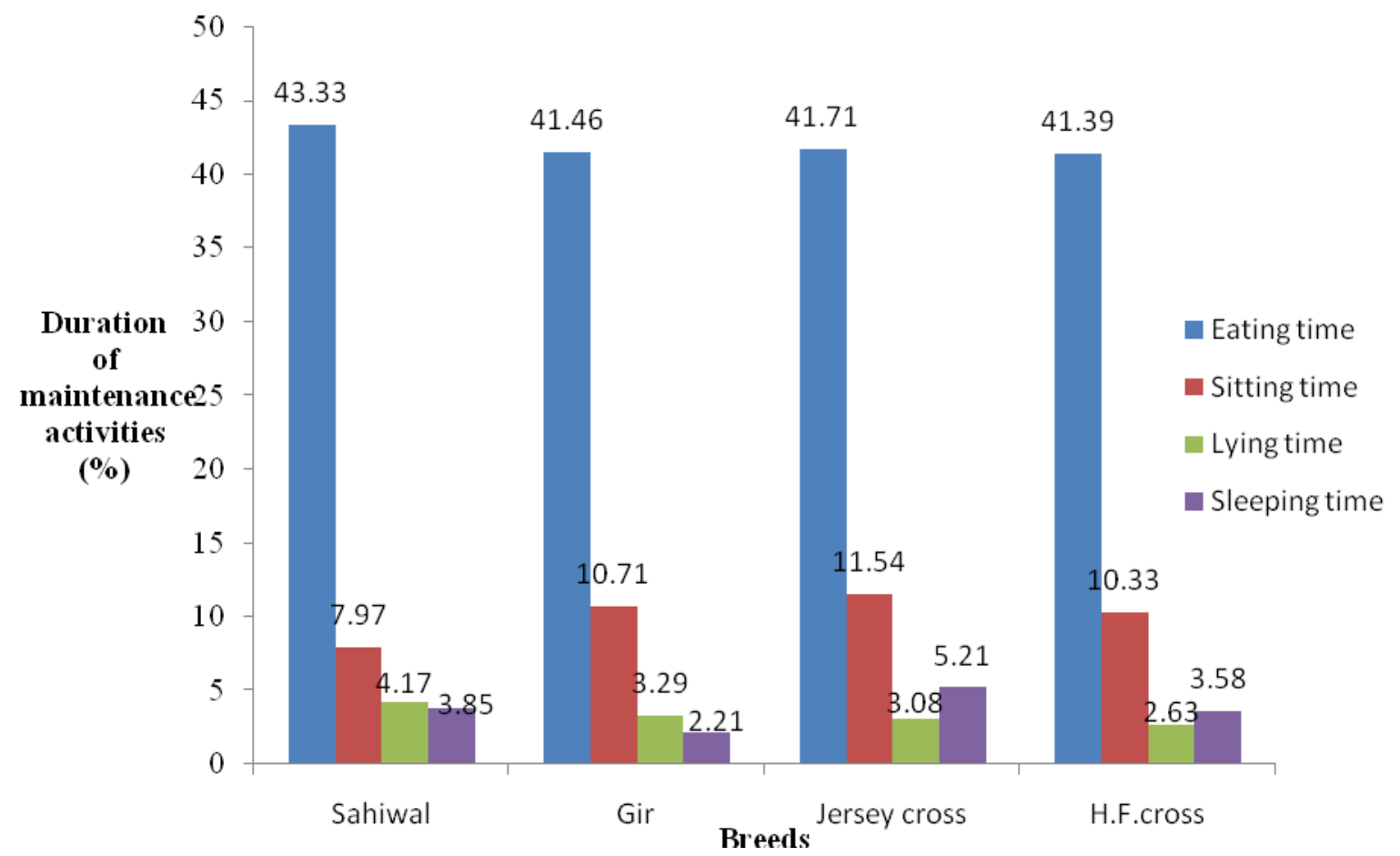

Fig.2 Effect of different breeds of stud bulls on duration of various maintenance activities (\%)

Higher values than that of the present findings were found by Singh et al., (1985) in cattle. But similar findings were reported by Mialon et al., (2008) in cattle. The variations found might be due to differences in age of the experimental animals.

\section{Sleeping time}

It is the time spent either in sitting or lying posture with closed eyes. Effects of breed and breed $\mathrm{x}$ season interaction on this parameter were significant statistically at 1 and $1 \%$ level respectively. Differences in sleeping time between Jersey cross and Sahiwal was found significant statistically $(\mathrm{P}<0.05)$. The mean sleeping time of bulls ranged from 2.21 to $5.21 \%$ (Fig.2). Breeds influenced the time spent in sleeping by the stud bulls in the order i.e., Jersey cross > Sahiwal > H.F. cross > Gir. Higher value $2.56 \mathrm{~min}$. (5.34\%) and 7.2 min. (5\%) per 48 min were reported by Jana et al., (1988) in crossbred cattle. These variations might be due to the age of animals and different management conditions.
Apparently sleeping activity shown by bulls of all breeds/ strains was more in winter than that during summer season. Similar findings were reported by Das (2001) in Sahiwal, Jersey cross and H.F cross cattle. The variation might be due to pleasant environmental condition in sunny winter. Different breeds responded differently in expression of various subcomponents of maintenance behavior during two seasons. Drinking and standing behavior appears to be more tolerant to different effects among allcomponents of postural behavior.

\section{Acknowledgement}

The authors are thankful to the Director, Frozen Semen Bull Station, Haringhata, Nadia, West Bengal, India for permitting to carry out the research work. It is also acknowledged to all the official veterinarians and staff members of the station for providing necessary support during the work period. 


\section{References}

Baumont R, Doreau M, Ingrand S and Veissier I. 2006. Feeding and masticating behavior in ruminants. Cambridge International Research 197: 84-107.

Das KS. 2001. Studies on prepartum management and its relationship with subsequent production and reproduction in crossbred dairy heifers. Ph.D. Thesis, I.V.R.I. (Deemed University), Izatnagar, Bareily, U.P., India.

Dumont B. 1996. Diet preference and selection at pasture. INRA Productions Animales. 9: 359-366.

Fraser AF and Broom DM. 2002. Farm Animal Behavior and Welfare, p. 423. 3rd edition, $\mathrm{CAB}$ International, University Press, Cambridge, Wallingford, UK.

Gonyou HW and Stricklin WR. 1984. Eating behavior of beef cattle groups fed from a single stall or trough. Applied Animal Ethology7: 123-133.

Harvey WR. 1990. User guide for LSMLMW and MIXMDL Package. Mix Model Least Squares and Maximum Likelihood Computer Programme. PC-2 version. Mimeograph, Columbia, Chio, USA.

Iraola J, Munoz E, García Y, Hernández JL, Tuero OJL and Moreira E. 2013.Feeding behavior of male cattle under restricted grazing supplemented with distiller maize grains during the dry period.Cuban Journal of Agricultural Sciences 47: 255.

Jana DN, Pandey HN, Srivastava BB and Pandey HS and Nautiyal LP. 1988. Daily behavioral pattern of cross bred cows(Abstract). National Symposium and IV Annual conference. 24$26^{\text {th }}$ September 1988. Makhdoom, India.

Lindstrom T, Redbo I and Uvnas-Moberg K. 2001. Plasma oxytocin and cortisol concentrations in dairy cows in relation to feeding duration and rumen fill. Physiology of Behaviour 72: 73-81.
Mialon MM, Allen MS and Aikman PC. 2008. Effects of the forage to concentrate ratio of the diet on feeding behavior in young Blond d' Aquitaine bulls. Animal Behaviour 2: 16821691.

Mitlohner FM, Morrow-Tesch JL, Wilson SC, Dailey JW and McGlone JJ. 2001. Behavioral sampling techniques for feedlot cattle. Journal of Animal Sciences 79: 1189-93.

Mounaix B, Boivin X, Brule, A and Schmitt T. 2013. Cattle behavior and the human - animal relationship in breeding. Applied Animal Behavioral Sciences 34: 22-5.

Rastani RR., Andrew SM, Zinn SA, Sniffen CJ. 2001. Body composition and estimated tissue energy balance in Jersey and Holstein cows during early lactation. Journal of Dairy Science, 84: 1201-1209.

Schake LM and Riggs JK. 1969. Diurnal and nocturnal activities of lactating beef cows in confinement. Journal of Animal Sciences 25: 254.

Singh MP, Karki DB, Mehta OP and Sastry NSR. 1985. Behavioral pattern of growing buffalo heifers under different housing conditions. Indian Journal of Dairy Sciences 38: 287-294.

Thind TS and Gill R.S. 1986. Ingestive behavior of lactating buffaloes kept under loose housing system. Indian Journal of Dairy Sciences 39: 41-46.

Thomson NA, Kay JK and Bryant MO. 2001. Effect of stage of lactation on the efficiency of Jersey and Friesian cows at converting pasture to milk production or live weight gain. Proceedings of the New Zealand Society of Animal Production 61: 213- 16.

Yadav JL and Gupta LR. 1985. Effects of housing and feeding system on the physiological reaction and behavior of milch buffalo during rainy season. Asian Journal of Dairy Research 4: 36.

\section{How to cite this article:}

Tripti Kumari, S. Pan and Choudhary. R. K. 2020. Study to Assess the Effect of Breed, Season and Breed $\mathrm{x}$ Season Interaction on Maintenance Behavior of Stud Bulls. Int.J.Curr.Microbiol.App.Sci. 9(06): 2833-2838. doi: https://doi.org/10.20546/ijcmas.2020.906.342 